\title{
Routine data for malaria morbidity estimation in Africa: challenges and prospects
}

\author{
Victor A. Alegana ${ }^{1,2,3^{*}}$, Emelda A. Okiro ${ }^{1}$ and Robert W. Snow ${ }^{1,4}$
}

\begin{abstract}
Background: The burden of malaria in sub-Saharan Africa remains challenging to measure relying on epidemiological modelling to evaluate the impact of investments and providing an in-depth analysis of progress and trends in malaria response globally. In malaria-endemic countries of Africa, there is increasing use of routine surveillance data to define national strategic targets, estimate malaria case burdens and measure control progress to identify financing priorities. Existing research focuses mainly on the strengths of these data with less emphasis on existing challenges and opportunities presented.
\end{abstract}

Conclusion: Here we define the current imperfections common to routine malaria morbidity data at national levels and offer prospects into their future use to reflect changing disease burdens.

Keywords: Malaria burden, Morbidity, Routine surveillance

\section{Background}

\section{Malaria burden estimation}

The precise burden of malaria in sub-Saharan Africa has remained elusive [1]. Infection with Plasmodium falciparum is a frequent event for individuals living in stable transmission areas in Africa, and not all new infections cause illness in part as a result of acquired immunity. Owing to the vagaries of malaria definitions and the ability to capture data from routine systems, the malaria community has defaulted to epidemiological models to estimate the morbid and fatal burdens of malaria [2-7]. While current burden estimation combines epidemiological modelling with aspects of routine data [6], the epidemiological models are based on sparse epidemiological

\footnotetext{
* Correspondence: valegana@kemri-wellcome.org

'Population Health Unit, Kenya Medical Research Institute - Wellcome Trust Research Programme, P.O. Box 43640, Nairobi 00100, Kenya

${ }^{2}$ Geography and Environmental Science, University of Southampton, Southampton SO17 1BJ, UK

Full list of author information is available at the end of the article
}

surveys, a presumed understanding of the relationship between infection and disease outcome, and despite increasing mathematical complexity over time, continue to be estimated with wide margins of uncertainty $[8,9]$. In the absence of empirical routine data on malaria morbidity, these models continue to be used by international agencies to prioritise malaria funding and to predict the impact of investment [10].

The National Malaria Strategic Plans (NMSPs) are developed to guide national partnerships on intervention delivery and ambition to reduce disease incidence in line with targets established by the Global Technical Strategy (GTS) for malaria [11]. In Table 1, 47 most recently available NMSPs show that targeted goals for national governments specify elimination in 14 countries, and the reduction in national case incidence in 33 countries not actively implementing elimination activities (Table 1 ). The ambitions of the NMSPs are articulated in terms of reducing case incidence. Furthermore, the sub-national theoretical priority setting is often represented through

(c) The Author(s). 2020 Open Access This article is licensed under a Creative Commons Attribution 4.0 International License, which permits use, sharing, adaptation, distribution and reproduction in any medium or format, as long as you give appropriate credit to the original author(s) and the source, provide a link to the Creative Commons licence, and indicate if changes were made. The images or other third party material in this article are included in the article's Creative Commons licence, unless indicated otherwise in a credit line to the material. If material is not included in the article's Creative Commons licence and your intended use is not permitted by statutory regulation or exceeds the permitted use, you will need to obtain permission directly from the copyright holder. To view a copy of this licence, visit http://creativecommons.org/licenses/by/4.0/ The Creative Commons Public Domain Dedication waiver (http://creativecommons.org/publicdomain/zero/1.0/) applies to the data made available in this article, unless otherwise stated in a credit line to the data. 
Table 1 Country-level national malaria strategy (NMS) policy goals in sub-Saharan Africa

\begin{tabular}{|c|c|c|c|c|}
\hline Country & $\begin{array}{l}\text { Classification } \\
\text { category }\end{array}$ & NMS period & National malaria strategy goal & $\begin{array}{l}\text { Sub-national representation } \\
\text { of malaria heterogeneity }\end{array}$ \\
\hline Botswana & Elimination & $2014-2018$ & $\begin{array}{l}\text { Achieve zero local malaria transmission in } \\
\text { Botswana by } 2018\end{array}$ & $A$ and $B$ \\
\hline Cape Verde & Elimination & $2014-2020$ & $\begin{array}{l}\text { Sustainably reduce the incidence of indigenous } \\
\text { malaria by } 2016 \text { and lay the foundations for its } \\
\text { elimination by } 2020\end{array}$ & No malaria map \\
\hline Comoros & Elimination & $2017-2021$ & $\begin{array}{l}\text { Reduce to zero cases of indigenous malaria } \\
\text { transmission in the Union of Comoros by } 2021\end{array}$ & A \\
\hline Eswatini & Elimination & $2015-2020$ & $\begin{array}{l}\text { Eliminate malaria by } 2015 \text { and achieve the WHO's } \\
\text { certification of elimination by } 2018\end{array}$ & B \\
\hline Namibia & Elimination & $2017-2022$ & $\begin{array}{l}\text { Achieve zero local malaria cases in Namibia by } \\
2022\end{array}$ & A \\
\hline São Tomé and Príncipe & Elimination & $2017-2021$ & $\begin{array}{l}\text { By } 2021 \text {, reduce malaria incidence to } 1 \text { case per } \\
1000 \text { population in all São Tomé districts and } 0 \text { (0) } \\
\text { indigenous cases in the Autonomous Region of } \\
\text { Príncipe }\end{array}$ & B \\
\hline South Africa & Elimination & 2019-2023 & $\begin{array}{l}\text { Achieve zero local malaria transmission in South } \\
\text { Africa by the year } 2023\end{array}$ & B \\
\hline Djibouti & Pre-elimination & 2013-2017 & $\begin{array}{l}\text { Reduce the prevalence of malaria parasite carriers } \\
\text { from } 0.64 \% \text { ( } 2008 \text { survey) to } 0 \% \text { to reach zero } \\
\text { indigenous cases by the end of } 2017\end{array}$ & $\mathrm{D}$ \\
\hline Rwanda & Pre-elimination & $2013-2020$ & $\begin{array}{l}\text { Reduce malaria morbidity by 30\% of 2015-2016 } \\
\text { level, by } 2020\end{array}$ & A \\
\hline Zanzibar & Pre-elimination & $2016-2020$ & Detecting and responding to malaria outbreaks & B \\
\hline Zimbabwe & Pre-elimination & $2016-2020$ & $\begin{array}{l}\text { Reduce malaria incidence to } 5 / 1000 \text { by } 2020 \\
\text { compared to } 2015 \text { levels }\end{array}$ & A \\
\hline Ethiopia & $\begin{array}{l}\text { Control and } \\
\text { elimination }\end{array}$ & $2014-2020$ & $\begin{array}{l}\text { Achieve } 75 \% \text { reduction in malaria cases from } \\
\text { baseline of } 2013 \text { by } 2020 \text {. Achieve falciparum } \\
\text { malaria elimination in selected low transmission } \\
\text { areas by } 2020 .\end{array}$ & A \\
\hline Somalia & $\begin{array}{l}\text { Control and } \\
\text { elimination }\end{array}$ & $2016-2020$ & $\begin{array}{l}\text { Reduce case incidence to }<1 \text { case per } 1000 \text { in } \\
\text { low transmission regions. Reduce case incidence } \\
\text { by } 40 \% \text { in control regions }\end{array}$ & $\mathrm{D}$ \\
\hline Zambia & $\begin{array}{l}\text { Control and } \\
\text { elimination }\end{array}$ & $2017-2021$ & $\begin{array}{l}\text { Reduce malaria incidence from } 336 \text { cases per } 1000 \\
\text { population in } 2015 \text { to less than } 5 \text { cases per } 1000 \\
\text { population by } 2019\end{array}$ & B \\
\hline Angola & Control & $2016-2020$ & $\begin{array}{l}\text { Reduce malaria morbidity by } 60 \% \text { in the country } \\
\text { by } 2020 \text { compared to the } 2012 \text { baseline. }\end{array}$ & E \\
\hline Benin & Control & $2017-2021$ & $\begin{array}{l}\text { Reduce the rate of incidence of malaria by at least } \\
25 \% \text { over the } 2015 \text { rate }\end{array}$ & $\mathrm{E}$ \\
\hline Burkina Faso & Control & 2014-2017 & Reduce morbidity by $75 \%$ compared to 2000 & No malaria map \\
\hline Burundi & Control & $2018-2023$ & Reduce malaria morbidity by at least $60 \%$ by 2023 & $A$ and $D$ \\
\hline Cameroon & Control & $2014-2018$ & $\begin{array}{l}\text { Reduce malaria incidence from } 2015 \text { levels by 60\% } \\
\text { by } 2023\end{array}$ & $\mathrm{E}$ \\
\hline The central African Republic & Control & $2016-2020$ & $\begin{array}{l}\text { Reduce the incidence of malaria by at least } 40 \% \text { in } \\
2020 \text { compared to } 2016\end{array}$ & $E$ \\
\hline Chad & Control & 2019-2023 & $\begin{array}{l}\text { Reduce malaria morbidity by } 75 \% \text { compared to } \\
\text { the } 2015 \text { level }\end{array}$ & $\mathrm{A}, \mathrm{D}$ and $\mathrm{E}$ \\
\hline Congo & Control & $2018-2022$ & $\begin{array}{l}\text { Reduce malaria incidence rate by } 86 \% \text { compared } \\
\text { to baseline rate in } 2015\end{array}$ & No Malaria Map \\
\hline Côte d'Ivoire & Control & $2016-2020$ & $\begin{array}{l}\text { Reduce the incidence of malaria by at least } 40 \% \\
\text { by } 2020 \text { compared to } 2015\end{array}$ & A \\
\hline The Democratic Republic of the Congo & Control & $2016-2020$ & $\begin{array}{l}\text { By 2020, reduce malaria-related morbidity by } 40 \% \\
\text { compared to } 2015 \text { levels }\end{array}$ & $\mathrm{D}$ and $\mathrm{E}$ \\
\hline Equatorial Guinea & Control & $2016-2020$ & $\begin{array}{l}\text { By } 2020 \text {, reduce by } 40 \% \text { the malaria morbidity } \\
\text { compared to the } 2015 \text { level }\end{array}$ & No malaria map \\
\hline Eritrea & Control & 2015-2019 & Reduce malaria incidence by 50\% from 2010 levels & $B$ and $D$ \\
\hline
\end{tabular}


Table 1 Country-level national malaria strategy (NMS) policy goals in sub-Saharan Africa (Continued)

\begin{tabular}{|c|c|c|c|c|}
\hline Country & $\begin{array}{l}\text { Classification } \\
\text { category }\end{array}$ & NMS period & National malaria strategy goal & $\begin{array}{l}\text { Sub-national representation } \\
\text { of malaria heterogeneity }\end{array}$ \\
\hline & & & $\begin{array}{l}\text { and achieve test positivity rate (TPR) below 5\% in } \\
\text { all sub-zones to shift to pre-elimination by } 2017 \\
\text { and beyond }\end{array}$ & \\
\hline Gabon & Control & 2018-2021 & $\begin{array}{l}\text { By } 2021 \text {, reduce malaria-related morbidity by at } \\
\text { least } 40 \% \text { compared to } 2015\end{array}$ & No malaria map \\
\hline The Gambia & Control & 2014-2020 & $\begin{array}{l}\text { Reduce malaria case incidence by at least } 40 \% \\
\text { compared with } 2013 \text {, by } 2020\end{array}$ & A \\
\hline Ghana & Control & $2014-2020$ & $\begin{array}{l}\text { Reduce malaria morbidity burden by } 75 \% \text { (using } \\
2012 \text { as baseline) by the year } 2020\end{array}$ & $\mathrm{D}$ and $\mathrm{E}$ \\
\hline Guinea & Control & 2018-2022 & $\begin{array}{l}\text { Achieve pre-elimination by } 2022 \text { by reducing } \\
\text { malaria morbidity by } 75 \% \text { compared to } 2016\end{array}$ & $\mathrm{D}$ and $\mathrm{E}$ \\
\hline Guinea-Bissau & Control & 2018-2022 & $\begin{array}{l}\text { Reduce malaria morbidity by at least 50\% } \\
\text { compared to } 2015\end{array}$ & No malaria map \\
\hline Kenya & Control & 2019-2023 & $\begin{array}{l}\text { Reduce malaria incidence and deaths by at least } \\
75 \% \text { of the } 2016 \text { levels by } 2023\end{array}$ & $\mathrm{D}$ \\
\hline Liberia & Control & $2016-2020$ & $\begin{array}{l}\text { By 2020, reduce illnesses caused by malaria by } \\
50 \% \text { compared to MIS } 2011 \text { baseline }\end{array}$ & $C$ and $D$ \\
\hline Madagascar & Control & 2013-2017 & $\begin{array}{l}\text { Reduce malaria-related morbidity to less than } 5 \% \\
\text { in } 50 \% \text { of districts and to less than 10\% in other } \\
\text { districts by the end of } 2017\end{array}$ & $A, B$ and $D$ \\
\hline Malawi & Control & $2017-2022$ & $\begin{array}{l}\text { To reduce malaria incidence by at least 50\% from } \\
\text { a } 2016 \text { baseline of } 386 \text { per } 1000 \text { population to } 193 \\
\text { per } 1000\end{array}$ & A \\
\hline Mali & Control & 2018-2022 & $\begin{array}{l}\text { Reduce malaria incidence by 50\% compared to } \\
2015\end{array}$ & $\mathrm{D}$ \\
\hline Mauritania & Control & $2014-2020$ & Achieving the goal of eliminating malaria by 2025 & $B$ and $E$ \\
\hline Mozambique & Control & $2017-2022$ & $\begin{array}{l}\text { Reduce malaria morbidity at a national level by at } \\
\text { least } 40 \% \text { compared to levels observed in } 2015 \text {, by } \\
2022\end{array}$ & $A$ and $D$ \\
\hline Niger & Control & $2017-2021$ & $\begin{array}{l}\text { Reduce the incidence of malaria by at least } 40 \% \\
\text { by } 2021 \text { compared to } 2015\end{array}$ & No malaria map \\
\hline Nigeria & Control & $2014-2020$ & Reduce malaria burden to pre-elimination levels & $\mathrm{D}$ \\
\hline Senegal & Control & $2016-2020$ & $\begin{array}{l}\text { Reduce the incidence of malaria by at least 75\% } \\
\text { compared to } 2014\end{array}$ & $A$ and $D$ \\
\hline Sierra Leone & Control & $2016-2020$ & $\begin{array}{l}\text { Reduce malaria morbidity by at least } 40 \% \\
\text { compared with } 2015 \text { by } 2020\end{array}$ & $\mathrm{D}$ \\
\hline South Sudan & Control & 2014-2021 & $\begin{array}{l}\text { Reduce the morbidity of malaria by } 80 \% \text { and } \\
\text { malaria parasite prevalence by } 50 \% \text { compared to } \\
2013 \text { by the year } 2020\end{array}$ & $\mathrm{D}$ \\
\hline Sudan & Control & $2018-2020$ & $\begin{array}{l}\text { Reduce malaria morbidity by 30\% by } 2020 \text { (taking } \\
2017 \text { as a baseline) }\end{array}$ & $\mathrm{D}$ \\
\hline Tanzania & Control & $2014-2020$ & $\begin{array}{l}\text { Reduce the average country malaria prevalence } \\
\text { from 10\% in } 2012 \text { to } 5 \% \text { in } 2016 \text { and further in } \\
2020 \text { to less than } 1 \% \text {. }\end{array}$ & $\mathrm{D}$ \\
\hline Togo & Control & $2017-2022$ & $\begin{array}{l}\text { Reduce malaria morbidity in the general } \\
\text { population }\end{array}$ & A \\
\hline Uganda & Control & $2014-2020$ & $\begin{array}{l}\text { Reduce malaria morbidity to } 30 \text { cases per } 1000 \\
\text { population by } 2020 \text {. Reduce the malaria parasite } \\
\text { prevalence to less than } 7 \% \text { by } 2020 \text {. }\end{array}$ & $\mathrm{D}$ \\
\hline
\end{tabular}

For each county, the malaria vision, mission was reviewed. This table only summarises the main objective stated in the NMS. For sub-national heterogeneity, A represents the map of case incidence; B, map of malaria cases; $C$, map based on test positivity rate (TPR); D, map based on parasite prevalence; and $\mathrm{E}$, map of climate/seasonal/ecological suitability

case incidence maps in 21 countries or based on the number of reported malaria cases from routine data (Table 1). Thirteen countries use parasite prevalence and
7 countries use climate-based maps within NMSPs to define the sub-national heterogeneity of risk. At the launch of the Roll Back Malaria initiative, 20 years ago, 
the use of any data to provide a strategic direction at national levels was rare. There is now at least a recognition that data should be used to inform national targets and priority setting. Whether, at the country level, data is used to provide sub-national priorities or used to measure if malaria targets are met is less clear.

The increasing use of nationally owned surveillance data to define malaria burdens has likely emerged because of three key important initiatives. Firstly, the ability to define malaria-specific morbidity presenting to the health services has been improved substantially with the universal acceptance across Africa of the Test. Treat. Track (T3) initiative [12], facilitated by the innovation in point-of-care, malaria rapid diagnostic tests (mRDTs). Between 2010 and 2018, over 1 billion mRDTs have been performed in Africa [13]. Secondly, there has been a recognition that routine data should form the basis of improved malaria control. In 2015, the GTS was developed and transformed malaria surveillance into a core malaria intervention. Finally, across Africa since 2010, there has been an unprecedented harmonisation of electronic health data management platforms, especially the District Health Information Systems (DHIS2) [14, 15] (Fig. 1). This adaptable electronic data platform has enabled malaria programmes to work with national health information partners to ensure there are malaria dashboards that capture data, from public and private health sectors.

Clearly, countries in Africa aiming to eliminate the parasite nationwide, or within defined geographic areas, are required to identify all cases of the disease and new infections. Countries in this category include Cape Verde, Comoros, São Tomé and Príncipe, South Africa and Eswatini (Table 1; Fig. 2), where the WHO uses the actual cases of malaria reported as the definitive number of new malaria cases each year. The challenges associated with surveillance in identifying every new infection for elimination have been considered elsewhere $[9,17,18]$.

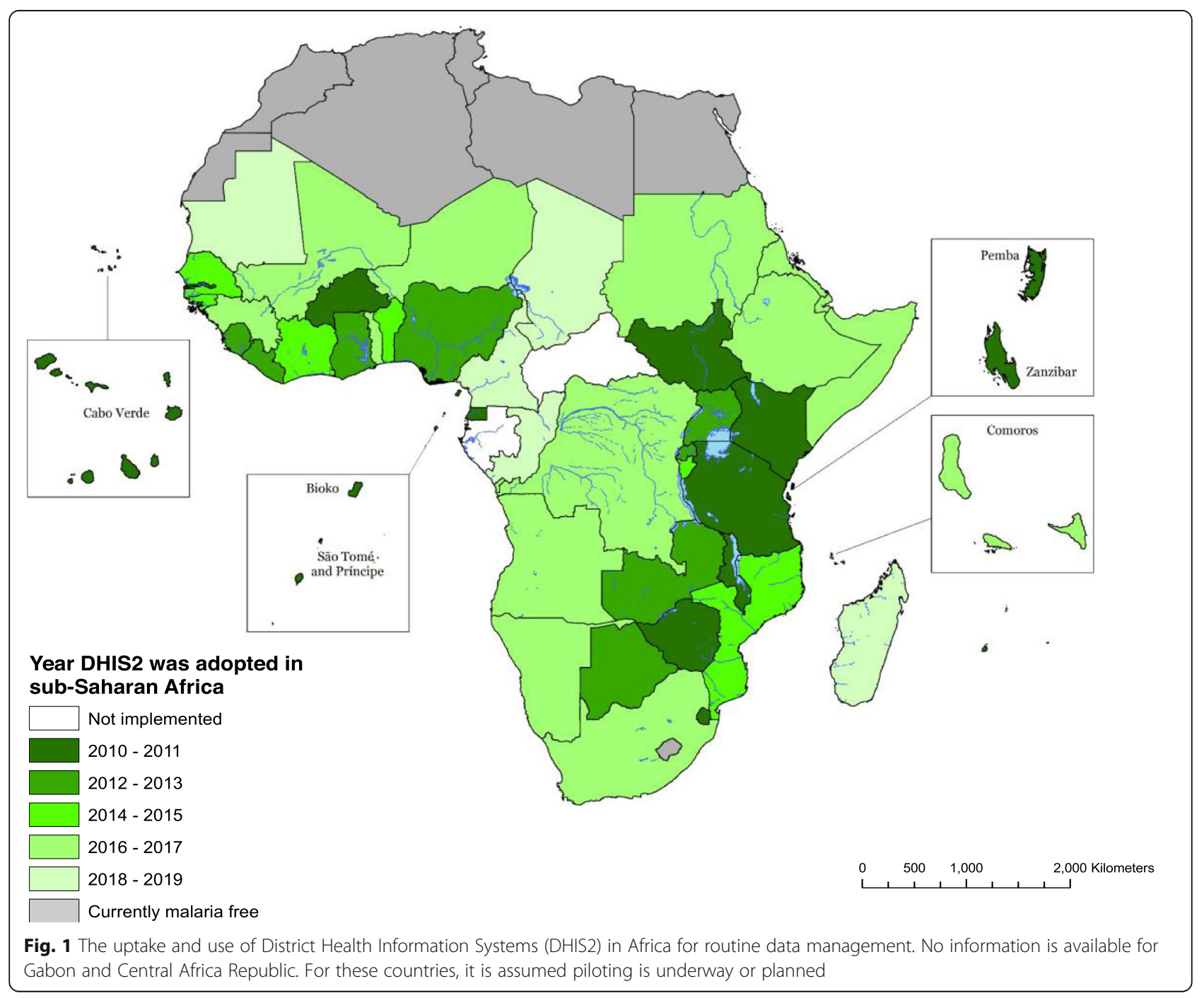




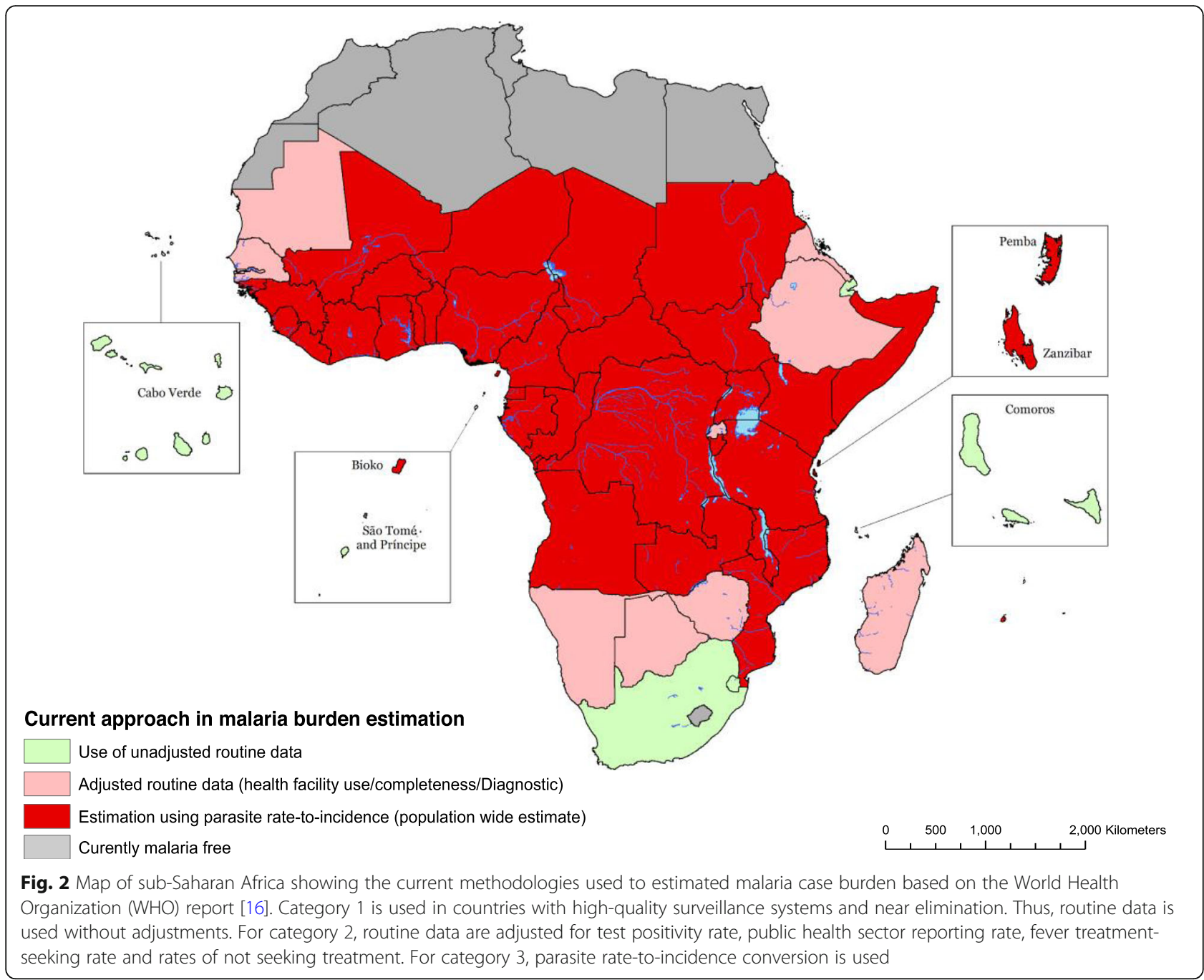

With improvements in detection, treatment and reporting, several other countries provide routine data to the WHO for their World Malaria Report (WMR), including Botswana, Eritrea, Ethiopia, The Gambia, Madagascar, Mauritania, Namibia, Rwanda, Senegal and Zimbabwe (Fig. 2). Case data in these second-tier countries are adjusted to reflect cases that might have been missed from formal reporting systems [13]. However, for 30 countries in SSA, the WHO [13] uses modelled predictions from a composite of interpolated, modelled parasite infection prevalence surveys undertaken infrequently, and transformed to case incidence using a modelled non-linear relationship between parasite prevalence and active case detection from 30 epidemiological studies undertaken between 10 and 20 years ago [19] (Fig. 2). Outside of Africa, routine data reported by national malaria control programmes are almost universally used as a direct estimate of the clinical burden per country. One obvious ambition of the WHO's GTS is that all countries worldwide have robust, reliable and timely surveillance, avoiding reliance upon uncertain modelled estimates of malaria disease burden.

\section{Main text \\ Components of reliable routine surveillance for malaria morbidity burden estimation}

Surveillance involves the continuous collection and use of data to inform health policy and decision-making. However, there are challenges for Routine Health Information System (RHIS) related to the technical processes (e.g. data flow, recording forms, system-related), organisational (e.g. resources, structures, information cultures) and user behavioural (e.g. health worker knowledge, skills, attitudes). Reviews on the technical challenges and improvements in RHIS are presented elsewhere [14, 20, 21]. Many of these equally apply to malaria; however, there are several aspects of malaria burden estimation through RHIS that require specific consideration.

The use of routine data for malaria morbidity estimation requires an understanding of the denominator population 
from which the cases originate, completeness and demographics of the number of reported malaria cases, and the uncertainties or biases associated with these quantities. Ideally, all fevers that could be malaria occurring within a community must reach a facility where parasitological testing is provided, and all these events are accurately recorded and stored within a real-time electronic data capture system, such as DHIS2 (Fig. 3). This is rarely the case in Africa settings, and until this ideal is reached, there is a need to estimate the numbers of fevers not reaching diagnostic centres, the fraction tested, and of those who do not reach testing centres or those untested, the presumed fraction positive. The variance from the ideal to reality can be a result of multiple factors. These factors and components of RHIS are discussed below and demonstrated in Fig. 3.

\section{The denominator population}

One starting point is an understating of population denominator from which malaria cases arise. Fine-scale census data is often not available or accessible to NMPs. Population censuses are conducted every 10 years and, in some countries (the Central African Republic, the Democratic Republic of the Congo, Eritrea, Somalia and Madagascar), the last census was conducted over two decades ago $[22,23]$. In countries with a recent census, data is not always accessible at granular age or finespatial scales. This highlights a broader interoperability issue between government ministries and departments. Timely and fine-scale census data is fundamental to understanding health access, health service catchments and sub-national disease burden. Consequently, coarse-scale census data is used to provide open-access populationdensity surfaces, disaggregated to a fine-scale using weighted dasymetric mapping [24-29]. These include $1 \times 1 \mathrm{~km}$ gridded population surfaces produced by Worldpop [30], Gridded Population of the World (GPW) [31], LandScan [32] and Facebook [33], with Worldpop being the most frequently used in malaria burden estimation [5-7, 13]. Modelling of imperfect spatial and temporal census data comes with uncertainty $[34,35]$ and cannot replace empirical local, fine-scale population data if these were made more accessible. There are new innovative methods of mapping population combining social media platforms with satellite remote sensing via machine learning methods [36], or triangulating data from human settlements with mobile phones [37]. Integrating these novel methods of human population and settlement locations into more efficient definitions of health facility catchments should be encouraged.

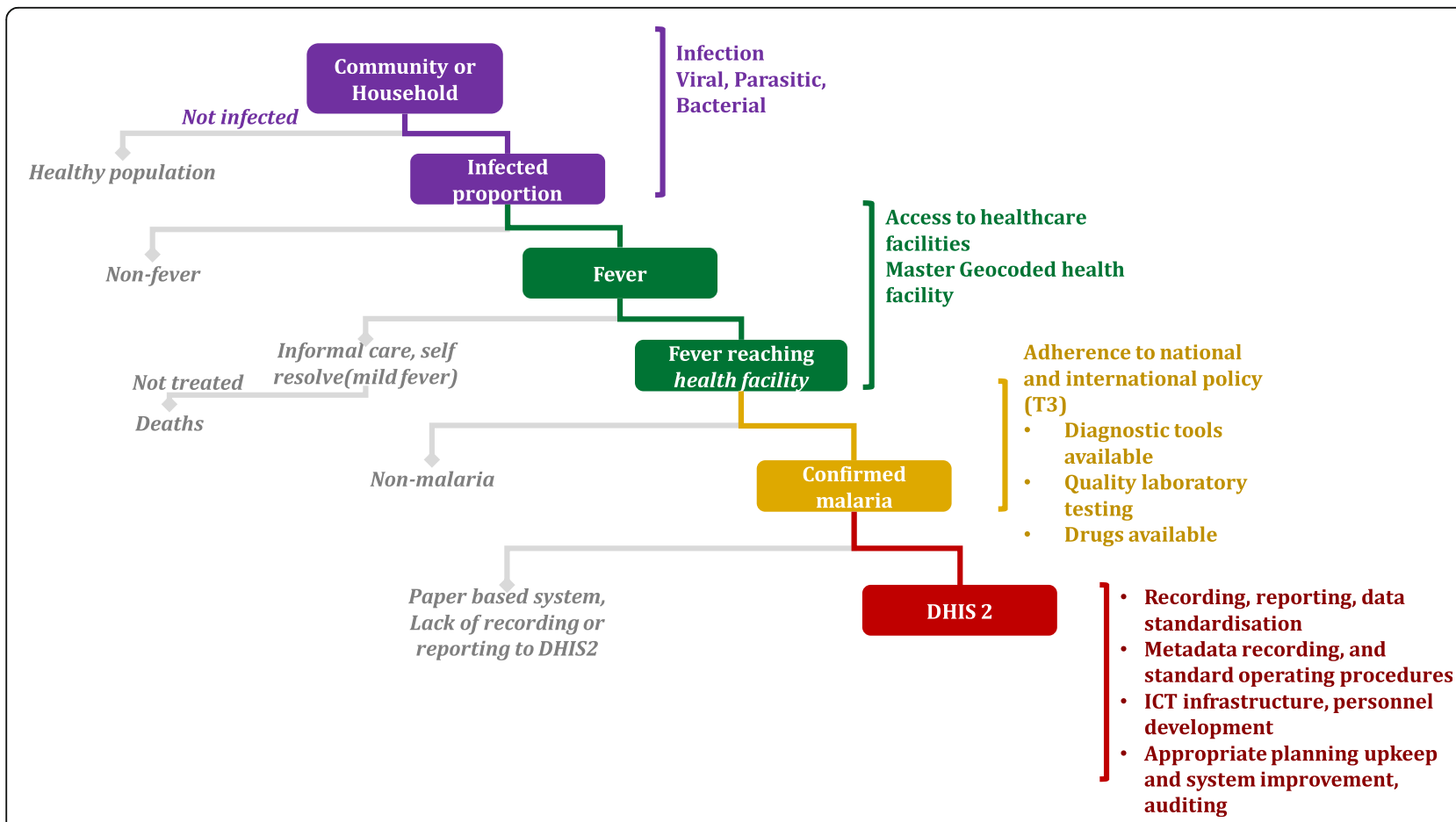

Fig. 3 Ideal malaria routine data flow. The ideal system would require all fever cases occurring at community-level use health facilities and that a complete geo-coded master health facility list. Fever cases presenting at health facilities are then tested for malaria under the Test.Treat.Track (T3) initiative. Thus, appropriate diagnostics or laboratory tools should be available at the health facility, the quality of laboratory testing should be highest, there should be no drug stock-outs and the treatment of fever case should be based on the national guidelines at the health facility. Finally, all confirmed malaria cases at the health facility should be recorded accurately and reported promptly to the national surveillance system such as DHIS2 
Malaria-morbidity-specific catchments are important in interpreting facility-level enumerations of the case burden and identifying those populations marginalised from formal health services [38-41]. Ideally, the definition or the demarcation of a health facility catchment should be based on choices made by patients seeking care at the health facility rather than solely on proximity (distance) [42-44]. Patient choice of health services depends on many individual-level factors described earlier (location and behaviour) and system factors such as competition between accessible service providers. Improvement in catchment demarcation could, therefore, be improved by integrating these demand and supply factors, from DHIS2, with community-level factors.

\section{A Master Health Facility List}

In defining catchment population, an important aspect is whether the DHIS2 represents the universe of all healthcare providers within a country. Censuses of healthcare providers are increasing in scope and coverage across Africa, through the Master Health Facility List (MHFL) initiative [45]. MHFL has been established and updated in 11 countries (Burundi, Botswana, The Democratic Republic of the Congo, Malawi, Namibia, Nigeria Rwanda, Kenya, Swaziland and Zimbabwe). While this should form the basis of examining the completeness of reporting from formal health provider sectors, many other countries do not have an updated and available census of providers, and fewer are georeferenced for use in a more granular form to examine sub-national heterogeneity or understand the completeness in fever diagnosis [46].

\section{Variation in fever treatment-seeking behaviour}

Malaria fevers among semi-immune populations can be self-limiting, and patients may not seek treatment. Sources of general fever treatment are manifold. Individuals and caretakers seek fever treatment from medicines available at home, shops, drug vendors, private informal healthcare providers and formal health sector, and polypharmacy is common $[47,48]$. For example, the latest WMR states that approximately $36 \%$ (interquartile range [IQR] 28-45\%) of children in SSA with a fever in the last 2 weeks did not seek treatment [13]. Data has been used to map the variation in fever treatment-seeking among children across Africa using household survey data on the actions taken for fevers reported by carers over the last 14 days [49-51]. These household surveys rarely capture the complexity of first, second, or third sources of treatment; cannot define what treatments might be sought after the interview; and do not capture febrile populations older than 5 years.

Patient choice depends on different factors such as the distance, social, cultural, costs, and attractive properties of the health facility [52-58]. Referrals from one sector to a higher-level facility are complex; patients frequently by-pass their nearest service provider for several reasons $[59,60]$. Surprisingly, little is known about the choices made for treatment by febrile children, including the contextual nature of choice (disease and healthcare quality perceptions or geographic access) [44, 61].

There is limited information on malaria patient groups outside of childhood. The risks of fevers associated with malaria infection, treatment-seeking, diagnostic use and documentation among non-pregnant adults in Africa are rarely described. Aggregated routine data is often reported by age groups above and below 5 years, limiting the ability to understand the epidemiology of malaria morbidity in the entire community by age [62]. The highest burden of severe malaria and malaria mortality is concentrated among young children. However, infection and mild clinical disease continue to pose a burden on adolescents [63] and less so in non-pregnant adults $[64,65]$.

There is a need to understand treatment choices to define malaria fevers likely to be missed through routine data. This will require more in-depth quantitative survey questions combined with qualitative methods across all age groups.

\section{Malaria testing}

Not all fevers reaching the health facility are tested for the presence of malaria parasites [66]. For decades, healthcare providers in malaria-endemic areas treated all fevers as malaria presumptively [67-70]. In 2011, the international malaria case-management guidelines were changed to improve parasitological testing and treatment adherence to malaria test results $[12,71]$. This has now been adopted widely across SSA. According to the latest WMR, over 66\% (IQR 49-75\%) of childhood fevers presenting to a formal healthcare providers in 20 SSA countries were reported to have been subjected to a parasitological test [13]. This remains a long way from universal testing of all fevers presenting to health facilities with a capability of providing this service. The variation between and within country in testing rates can result from inadequate training and lack of supervision of healthcare workers [72-74], shortages and stock-outs of equipment and mRDTs [75, 76], and patient-level factors $[77,78]$. These are health system issues that are surmountable by improving in-service training, stock management and logistics. Importantly, the RHIS can identify these failings to specific health facilities, becoming a self-regulating district supervisory tool.

However, universal parasitological testing is more challenging among those who seek treatment in the informal private sector or at home. Efforts to roll out mRDTs through community healthcare workers [79-83] 
or informal retailers [84-86] are underway, and these are currently reported to the DHIS2 at health facilities where the community health worker is attached or through mobile systems. Ensuring quality diagnosis and treatment as close to the home as possible is critical to ensuring appropriate treatment. However, for morbidity burden estimation and surveillance, innovation is required to ensure all cases are documented and tracked effectively.

Presently, malaria routine data that is used by the WHO for burden estimation presumes that the fraction of parasite-positive fevers in the formal health sector are the same as those who remain untreated or treated in the informal sector. Few empirical surveys have examined infection prevalence in childhood fevers in the community versus those reaching facilities $[39,65,87$, 88 ], or those seen at accredited drug stores versus formal health facilities [89]. This represents a data gap and needs further exploration, across all age groups, to validate corrections made to fever incidence that does not reach facilities.

With more empirical parametrisation of how malaria fevers are treated and choices at a household level, more formal statistical approaches might be applied to malaria treatment-seeking behaviour data. This can then be combined with DHIS2 to improve the understanding of events missed. Understanding the contextual factors that influence choices, including distance to services, seasonal influences on access, service quality, service costs and poverty could be integrated within geo-statistical platforms that could accommodate multiple levels of predictive information that would not assume all treatment-seeking is uniform within a single country. Examples of how individuals interact with health systems have been developed using probit behavioural models that incorporate latent variables, for example, Item Response Theory [90-93], that also allow the quantification of unobserved individual-level traits influencing behavioural outcomes.

Currently, mRDTs are replacing microscopy as the diagnostic of choice. The most commonly used mRDTs detect antigens produced by Plasmodium parasites circulating in the blood such as the Plasmodium falciparum histidinerich protein-2 (PfHPR2) or Plasmodium falciparum histidine-rich protein-3 (PfHPR3) [94]. Evolutionary fitness to avoid detection has resulted in deletions in the parasite to PfHPR2/3 in SSA [95-97]. The extent or distribution of this phenomenon in other settings in Africa is not yet clear. The current recommendation is using mRDTs that do not exclusively rely on PfHPR $2 / 3$ in areas where PfHPR2/3 deletions are found prevalent [98]. This will require a dual approach to surveillance of PfHRP2/3 deletions and innovation in new mRDTs.

\section{Coverage of routine data for decision-making in DHIS2}

While there has been rapid adoption of DHIS2 across Africa (Fig. 1), barriers exist related to data access, data quality, transparency, use at international and national levels [99] and the existence, in some countries, of multiple data systems operating in parallel. Operationally, routine data systems use multiple registers for data capture at the health facility level. These are typically located in different departments such as the outpatient departments, the inpatient department, antenatal clinics and the laboratory. The variation in data capture and multiple recording contribute to inconsistencies and delays while transferring data from registers to aggregate (facility-month) malaria cases and subsequent reporting in DHIS2 [100-104].

Incomplete reporting of routine data is common across all surveillance systems. This might include facilities never reporting, facilities missing some months of data, and incomplete reporting of data elements. The former requires a complete inventory of facilities. Monthly data might be available at the health facility level or aggregated across time and districts. Aggregated data present challenges in understanding the true completeness and masks data quality issues at various service delivery points at the health facility level [105]. When facility-level data exhibits missingness, then statistical imputation techniques can be employed: for example, using moving averages within the longer-term data at that facility $[106,107]$ or including neighbouring facility data and information on seasonality through modelbased framework [108-111]. While data incompleteness requires health system interventions and quality assurance methods, dealing with incomplete data remains an academic exercise. National Malaria Programmes (NMPs) require skills to understand the impact and statistical consequences of incomplete data and training in simplified tools to improve sub-national disease burden estimation. Developing capacity within NMPs for effective analysis (spatial or non-spatial analysis) of routine health facility data, visualisation (e.g. using Geographic Information Systems) and their interpretation to promote a culture of evidence-driven decision-making requires long-term, sustainable investment [112, 113], circumventing the need for externally driven analysis of national data.

\section{Other uses of routine data}

Routine data are not only used by national malaria programmes to define disease burden. Other routine metrics provided by DHIS2 include fever test positivity rates (TPR) which have historically been used to define malaria stratification to target resources for elimination [114, 115]. Tanzania provides recent examples of using the routine DHIS2 TPR data for sub-national 
stratification for fevers [116, 117] and pregnant women attending antenatal clinics $[118,119]$. Routine data also provides the bedrock for commodity supplies, drugs, diagnostics and prevention (long-lasting treated nets, intermittent presumptive treatment). While less critically dependent on the definition of the populations they serve $[9,40]$, many of the elements of care-seeking, infected populations and those missed by routine data apply equally to the representativeness of TPR and those marginalised from health services.

\section{Conclusion}

The GTS has ambitious long-term goals, including elimination. Surveillance is considered as a core intervention and a third pillar for the GTS. However, there continues to remain a focus on what commodities (including their costs) are required for disease treatment and prevention, and less on how to improve disease burden estimation at national levels. Improving burden estimation is fundamental for efficient allocation, use of resources and examining whether they have the desired impact on disease burden. The High Burden to High Impact: A Targeted Malaria Response [120] has begun to introduce the notion that using data to inform strategic investment is central to maximising impact. Data remain imperfect; however, with a more detailed understanding of their representativeness, missingness and epidemiological context, these data can replace modelled estimations of morbidity anchored in parasite prevalence. At the very least, data from routine reporting is a continuous measure, providing information every month of every year, unlike underpowered parasite prevalence surveys undertaken every $3-5$ years [121-123]. Some of the data gaps in improving our understanding of the precision of routine malaria data are summarised in Table 2.

Not considered in this paper is that there is an equivalent need to examine how we define malaria mortality burdens. Measuring the achievement of zero malaria deaths requires a parallel interrogation of data systems, including the veracity of cause of death attribution and improving civil registration [124, 125], not considered here.

Table 2 Outstanding questions and data gaps

\footnotetext{
- Improving access to national data on fine resolution census and meteorological data

- Explore new methods of defining local population denominators and catchments

- Improving geo-coded inventories of health service providers

- Improved understanding of fever incidence, infection risk and treatment-seeking patterns across all age groups and genders, including better structured quantitative and qualitative methodologies

- Developing tools for tracking quality of data in routine data systems

- Surveillance for PfHRP2/3 deletions

- Building long-term, sustainable capacity in national malaria programmes (NMPs) to understand, interrogate, display and interpolate routine malaria data
}

The modelled estimation of malaria mortality is more complex [5, 126, 127], more uncertain [128, 129] and less well represented by national death registration [130-132].

If the GTS is to succeed, it should be linked to investment in routine malaria surveillance, not limited to those countries aiming for elimination, but all countries across SSA. As more countries improve their routine morbidity surveillance, and the map shown in Fig. 2 changes, new estimates of the malaria burden in Africa will emerge. The challenge is then to persuade the international community that these new estimates will not indicate a rise or fall in malaria burden, but an improvement in estimation. A sensible metric of success for the GTS would be a national ability to define its own subnational malaria morbidity burden.

\section{Acknowledgements}

The authors would like to thank Khoti Gausi, Spes Caritas and Abderahmane Kharchi of WHO AFRO regional offices for the help in accessing the National Malaria Strategic Plans (NMSPs) used in this review. We also acknowledge earlier discussions with Abdisalan Noor of WHO GMP and comment on the version of the manuscript by Peter Macharia, George Okello and Sam Akech all of KEMRI - Wellcome Trust Research Programme.

\section{Authors' contributions}

V.A.A. and R.W.S. conceived and designed the study review and were responsible for the production of the first drafts of the manuscript. E.A.O. reviewed subsequent drafts. All authors reviewed, edited and approved the final manuscript.

\section{Funding}

V.A.A. is funded through a Wellcome Trust Training Fellowship (\# 211208). EAO is supported through a Wellcome Trust Intermediary Fellowship (\# 201866). R.W.S. is funded by Wellcome Trust Principal Fellowship (\#s 103602 \& 212176). V.A.A, E.A.O. and R.W.S. acknowledge the support of the Wellcome Trust to the Kenya Major Overseas Programme (\# 203077). The funder had no role in the study design, data collection, data preparation or writing of the report.

\section{Availability of data and materials}

No data analysis was conducted using primary or secondary data.

Ethics approval and consent to participate

Not applicable

Consent for publication

Not applicable

\section{Competing interests}

Authors declare no competing interests.

\section{Author details}

${ }^{1}$ Population Health Unit, Kenya Medical Research Institute - Wellcome Trust Research Programme, P.O. Box 43640, Nairobi 00100, Kenya. ${ }^{2}$ Geography and Environmental Science, University of Southampton, Southampton SO17 1BJ, UK. ${ }^{3}$ Faculty of Science and Technology, Lancaster University, Lancaster LAI 4YW, UK. ${ }^{4}$ Centre for Tropical Medicine and Global Health, Nuffield Department of Clinical Medicine, University of Oxford, Oxford OX3 7LJ, UK.

Received: 4 February 2020 Accepted: 14 April 2020

Published online: 03 June 2020

\section{References}

1. Snow R. Sixty years trying to define the malaria burden in Africa: have we made any progress? BMC Med. 2014;12(1):227. 
2. Snow RW, Guerra CA, Noor AM, Myint HY, Hay SI. The global distribution of clinical episodes of Plasmodium falciparum malaria. Nature. 2005;434(7030): 214-7.

3. Hay SI, Guerra CA, Gething PW, Patil AP, Tatem AJ, Noor AM, Kabaria CW, Manh BH, Elyazar IR, Brooker S, et al. A world malaria map: Plasmodium falciparum endemicity in 2007. PLoS Med. 2009;6(3):e1000048.

4. Noor AM, Kinyoki DK, Mundia CW, Kabaria CW, Mutua JW, Alegana VA, Fall IS, Snow RW. The changing risk of Plasmodium falciparum malaria infection in Africa: 2000-10: a spatial and temporal analysis of transmission intensity. Lancet. 2014:383(9930):1739-47.

5. Gething PW, Casey DC, Weiss DJ, Bisanzio D, Bhatt S, Cameron E, Battle KE, Dalrymple U, Rozier J, Rao PC, et al. Mapping Plasmodium falciparum mortality in Africa between 1990 and 2015. N Engl J Med. 2016;375(25): 2435-45.

6. Weiss DJ, Lucas TCD, Nguyen M, Nandi AK, Bisanzio D, Battle KE, Cameron E, Twohig KA, Pfeffer DA, Rozier JA, et al. Mapping the global prevalence, incidence, and mortality of Plasmodium falciparum, 2000-17: a spatial and temporal modelling study. Lancet. 2019;394(10195):322-31.

7. Bhatt S, Weiss DJ, Cameron E, Bisanzio D, Mappin B, Dalrymple U, Battle KE, Moyes CL, Henry A, Eckhoff PA, et al. The effect of malaria control on Plasmodium falciparum in Africa between 2000 and 2015. Nature. 2015; 526(7572):207-11.

8. Cibulskis RE, Aregawi M, Williams R, Otten M, Dye C. Worldwide incidence of malaria in 2009: estimates, time trends, and a critique of methods. PLoS Med. 2011;8(12):e1001142.

9. Nkumama IN, O'Meara WP, Osier FHA. Changes in malaria epidemiology in Africa and new challenges for elimination. Trends Parasitol. 2017:33(2):128-40

10. Feachem RGA, Chen I, Akbari O, Bertozzi-Villa A, Bhatt S, Binka F, Boni MF, Buckee C, Dieleman J, Dondorp A, et al. Malaria eradication within a generation: ambitious, achievable, and necessary. Lancet. 2019:394(10203):1056-112.

11. World Health Organization. Global technical strategy for malaria 2016-2030. Geneva: WHO; 2015. Available at: https://www.who.int/malaria/publications/ atoz/9789241564991/en/.

12. World Health Organization. Test. Treat. Track. Scaling up diagnostic testing, treatment and surveillance for malaria. Geneva: World Health organization; 2012. Available at: http://www.who.int/malaria/publications/atoz/test_treat_ track_brochure.pdf.

13. World Health Organization. World malaria report 2019. Geneva: World Health organization; 2019. Available at: https://www.who.int/publicationsdetail/world-malaria-report-2019.

14. Dehnavieh R, Haghdoost A, Khosravi A, Hoseinabadi F, Rahimi H, Poursheikhali A, Khajehpour N, Khajeh Z, Mirshekari N, Hasani M, et al. The District Health Information System (DHIS2): a literature review and metasynthesis of its strengths and operational challenges based on the experiences of 11 countries. Health Inf Manage J. 2018:48(2):62-75.

15. World Health Organization. Malaria surveillance, monitoring \& evaluation: a reference manual. Geneva: WHO; 2018.

16. World Health Organization. World malaria report 2018. Geneva: World Health organization; 2018. Available at: http://www.who.int/malaria/ publications/world-malaria-report-2017/report/en/.

17. Sturrock HJW, Bennett AF, Midekisa A, Gosling RD, Gething PW, Greenhouse B. Mapping malaria risk in low transmission settings: challenges and opportunities. Trends Parasitol. 2016;32(8):635-45.

18. Sturrock HJW, Hsiang MS, Cohen JM, Smith DL, Greenhouse B, Bousema T, Gosling RD. Targeting asymptomatic malaria infections: active surveillance in control and elimination. PLoS Med. 2013;10(6):e1001467.

19. Cameron E, Battle KE, Bhatt S, Weiss DJ, Bisanzio D, Mappin B, Dalrymple U, Hay SI, Smith DL, Griffin JT, et al. Defining the relationship between infection prevalence and clinical incidence of Plasmodium falciparum malaria. Nat Commun. 2015;6:8170

20. MEASURE Evaluation. Tools for data demand and use in the health sector. Performance of Routine Information Systems Management (PRISM) tools. Chapel Hill: USAMEASURE Evaluation; 2011. Available at: https://www. measureevaluation.org/resources/tools/health-information-systems/prism.

21. Aqil A, Lippeveld T, Hozumi D. PRISM framework: a paradigm shift for designing, strengthening and evaluating routine health information systems. Health Policy Plan. 2009;24(3):217-28.

22. UN Department of Economic and Social Affairs Population Division: World population prospects: the 2017 revision, data booklet, 2017. Available at: https://www.un.org/en/development/desa/population/publications/index. shtml.
23. UN Department of Economic and Social Affairs Population Division: 2020 world population and housing census programme. https:/unstats.un.org/ unsd/demographic-social/census/censusdates/. Accessed 3 Feb 2019.

24. Wardrop NA, Jochem WC, Bird TJ, Chamberlain HR, Clarke D, Kerr D, Bengtsson L, Juran S, Seaman V, Tatem AJ. Spatially disaggregated population estimates in the absence of national population and housing census data. Proc Natl Acad Sci USA. 2018;115(14):3529-37.

25. Stevens FR, Gaughan AE, Linard C, Tatem AJ. Disaggregating census data for population mapping using random forests with remotely-sensed and ancillary data. PLoS One. 2015;10(2):e0107042.

26. Gaughan AE, Stevens FR, Linard C, Jia P, Tatem AJ. High resolution population distribution maps for Southeast Asia in 2010 and 2015. PLoS One. 2013:8(2):e55882.

27. Tatem A, Adamo S, Bharti N, Burgert C, Castro M, Dorelien A, Fink G, Linard C, Mendelsohn J, Montana L, et al. Mapping populations at risk: improving spatial demographic data for infectious disease modeling and metric derivation. Popul Health Metrics. 2012;10(1):8.

28. Balk DL, Deichmann U, Yetman G, Pozzi F, Hay SI, Nelson A. Determining global population distribution: methods, applications and data. Adv Parasitol. 2006;62:119-56.

29. Linard C, Tatem A. Large-scale spatial population databases in infectious disease research. Int J Health Geogr. 2012;11(1):7.

30. Worldpop: What is Worldpop? http://www.worldpop.org.uk/. Accessed 10 Nov 2018.

31. Center for International Earth Science Information Network. Gridded population of the world version 4: population density. Palisades: NYNASA Socioeconomic Data and Applications Center; 2019. Available at: https:// sedac.ciesin.columbia.edu/data/collection/gpw-v4.

32. Dobson JE, Bright EA, Coleman PR, Durfee RC, Worley BA. LandScan: a global population database for estimating populations at risk. Photogramm Eng Remote Sens. 2000;66(7):849-57.

33. Techcrunch: Facebook's Al team maps the whole population of Africa. https://techcrunch.com/2019/04/09/facebooks-ai-team-maps-out-whereeveryone-in-africa-lives/. Accessed 20 May 2019.

34. Murray CJL, Callender CSKH, Kulikoff XR, Srinivasan V, Abate D, Abate KH, Abay SM, Abbasi N, Abbastabar H, Abdela J, et al. Population and fertility by age and sex for 195 countries and territories, 1950-2017: a systematic analysis for the Global Burden of Disease Study 2017. Lancet. 2018. 392(10159):1995-2051.

35. Wheldon MC, Raftery AE, Clark SJ, Gerland P. Bayesian population reconstruction of female populations for less developed and more developed countries. Popul Stud. 2016;70(1):21-37.

36. Verhulst S, Young A. The potential of social media - intelligence to improve people's lives: social media data for good. New York: USAThe Governance Lab; 2017. Available at: https://ssrn.com/abstract=3141457.

37. Deville P, Linard C, Martin S, Gilbert M, Stevens FR, Gaughan AE, Blondel VD, Tatem AJ. Dynamic population mapping using mobile phone data. Proc Natl Acad Sci. 2014;111(45):15888-93

38. Alegana VA, Wright JA, Pentrina U, Noor AM, Snow RW, Atkinson PM. Spatia modelling of healthcare utilisation for treatment of fever in Namibia. Int J Health Geogr. 2012;11:6.

39. Oduro AR, Bojang KA, Conway DJ, Corrah T, Greenwood BM, Schellenberg D. Health centre surveys as a potential tool for monitoring malaria epidemiology by area and over time. PLoS One. 2011;6(11):e26305.

40. Kigozi SP, Kigozi RN, Sserwanga A, Nankabirwa Jl, Staedke SG, Kamya MR, Pullan RL. Malaria burden through routine reporting: relationship between incidence and test positivity rates. Am J Trop Med Hyg. 2019;101(1):137-47.

41. Boyce RM, Reyes R, Matte M, Ntaro M, Mulogo E, Lin F-C, Siedner MJ. Practical implications of the non-linear relationship between the test positivity rate and malaria incidence. PLoS One. 2016;11(3):e0152410.

42. Apparicio P, Abdelmajid M, Riva M, Shearmur R. Comparing alternative approaches to measuring the geographical accessibility of urban health services: distance types and aggregation-error issues. Int J Health Geogr. 2008;7:7.

43. Luo W, Qi Y. An enhanced two-step floating catchment area (E2SFCA) method for measuring spatial accessibility to primary care physicians. Health Place. 2009;15(4):1100-7.

44. Noor AM, Amin AA, Gething PW, Atkinson PM, Hay SI, Snow RW. Modelling distances travelled to government health services in Kenya. Tropical Med Int Health. 2006;11(2):188-96.

45. USAID, World Health Organization. Master facility list resource package: guidance for countries wanting to strengthen their MFL. Geneva: WHO/ 
USAID; 2018. Available at: https://www.who.int/healthinfo/MFL_Resource_ Package_Jan2018.pdf?ua=1.

46. Maina J, Ouma PO, Macharia PM, Alegana VA, Mitto B, Fall IS, Noor AM, Snow RW, Okiro EA. A spatial database of health facilities managed by the public health sector in sub Saharan Africa. Sci Data. 2019;6(1):134.

47. Goodman C, Brieger W, Unwin A, Mills A, Meek S, Greer G. Medicine sellers and malaria treatment in sub-Saharan Africa: what do they do and how can their practice be improved? Am J Trop Med Hyg. 2007;77(6 Suppl):203-18.

48. Mackintosh M, Channon A, Karan A, Selvaraj S, Cavagnero E, Zhao H. What is the private sector? Understanding private provision in the health systems of low-income and middle-income countries. Lancet. 2016;388(10044):596-605.

49. Battle KE, Bisanzio D, Gibson HS, Bhatt S, Cameron E, Weiss DJ, Mappin B, Dalrymple U, Howes RE, Hay SI, et al. Treatment-seeking rates in malaria endemic countries. Malar J. 2016;15(1):1-11.

50. Alegana VA, Maina J, Ouma PO, Macharia PM, Wright J, Atkinson PM, Okiro EA, Snow RW, Tatem AJ. National and sub-national variation in patterns of febrile case management in sub-Saharan Africa. Nat Commun. 2018;9(1):4994.

51. Ladner J, Davis B, Audureau E, Saba J. Treatment-seeking patterns for malaria in pharmacies in five sub-Saharan African countries. Malar J. 2017; 16(1):353.

52. Febir LG, Asante KP, Afari-Asiedu S, Abokyi LN, Kwarteng A, Ogutu B, Gyapong M, Owusu-Agyei S. Seeking treatment for uncomplicated malaria: experiences from the Kintampo districts of Ghana. Malar J. 2016;15(1):1-11.

53. Sundararajan R, Mwanga-Amumpaire J, Adrama H, Tumuhairwe J, Mbabazi S, Mworozi K, Carroll R, Bangsberg D, Boum li Y, Ware NC. Sociocultural and structural factors contributing to delays in treatment for children with severe malaria: a qualitative study in southwestern Uganda. Am J Trop Med Hygiene. 2015;92(5):933-40.

54. Matovu F, Nanyiti A, Rutebemberwa E. Household health care-seeking costs: experiences from a randomized, controlled trial of community-based malaria and pneumonia treatment among under-fives in eastern Uganda. Malar J. 2014;13:222.

55. Colvin CJ, Smith HJ, Swartz A, Ahs JW, de Heer J, Opiyo N, Kim JC Marraccini T, George A. Understanding careseeking for child illness in subSaharan Africa: a systematic review and conceptual framework based on qualitative research of household recognition and response to child diarrhoea, pneumonia and malaria. Soc Sci Med. 2013;86:66-78.

56. Chibwana Al, Mathanga DP, Chinkhumba J, Campbell CH Jr. Socio-cultural predictors of health-seeking behaviour for febrile under-five children in Mwanza-Neno district, Malawi. Malar J. 2009;8:219.

57. Tawiah T, Asante KP, Dwommoh RA, Kwarteng A, Gyaase S, Mahama E, Abokyi L, Amenga-Etego S, Hansen K, Akweongo P, et al. Economic costs of fever to households in the middle belt of Ghana. Malar J. 2016;15:68.

58. Dixit A, Lee MC, Goettsch B, Afrane Y, Githeko AK, Yan G. Discovering the cost of care: consumer, provider, and retailer surveys shed light on the determinants of malaria health-seeking behaviours. Malar J. 2016;15:179.

59. Leonard K, Mliga GR, Mariam DH. Bypassing health centers in Tanzania: revealed preferences for observable and unobservable quality. New York: Columbia University Academic Commons; 2002. Available at: https:// academiccommons.columbia.edu/catalog/ac:113198. Accessed 10 Dec 2019.

60. Akin JS, Hutchinson P. Health-care facility choice and the phenomenon of bypassing. Health Policy Plan. 1999;14(2):135-51.

61. Poyer S, Musuva A, Njoki N, Okara R, Cutherell A, Sievers D, Lussiana C, Memusi D, Kiptui R, Ejersa W, et al. Fever case management at private health facilities and private pharmacies on the Kenyan coast: analysis of data from two rounds of client exit interviews and mystery client visits. Malar J. 2018;17(1):112.

62. Githinji S, Noor AM, Malinga J, Macharia PM, Kiptui R, Omar A, Njagi K, Waqo E, Snow RW. A national health facility survey of malaria infection among febrile patients in Kenya, 2014. Malar J. 2016;15(1):591.

63. Lalloo DG, Olukoya P, Olliaro P. Malaria in adolescence: burden of disease, consequences, and opportunities for intervention. Lancet Infect Dis. 2006; 6(12):780-93.

64. Jenkins R, Omollo R, Ongecha M, Sifuna P, Othieno C, Ongeri L, Kingora J, Ogutu B. Prevalence of malaria parasites in adults and its determinants in malaria endemic area of Kisumu County, Kenya. Malar J. 2015;14:263.

65. Rulisa S, Kateera F, Bizimana JP, Agaba S, Dukuzumuremyi J, Baas L, de Dieu $\mathrm{HJ}$, Mens PF, Boer KR, de Vries PJ. Malaria prevalence, spatial clustering and risk factors in a low endemic area of Eastern Rwanda: a cross sectional study. PLoS One. 2013;8(7):e69443.
66. Plucinski MM, Guilavogui T, Camara A, Ndiop M, Cisse M, Painter J, Thwing J. How far are we from reaching universal malaria testing of all fever cases? Am J Trop Med Hygiene. 2018;99(3):670-9.

67. D'Acremont V, Lengeler C, Mshinda H, Mtasiwa D, Tanner M, Genton B. Time to move from presumptive malaria treatment to laboratory-confirmed diagnosis and treatment in African children with fever. PLoS Med. 2009;6(1): e252.

68. Herlihy JM, D'Acremont V, Hay Burgess DC, Hamer DH. Diagnosis and treatment of the febrile child. In: Black RE, Laxminarayan R, Temmerman M, Walker N, editors. Reproductive, maternal, newborn, and child health: disease control priorities. Volume 2. Washington (DC), The World Bank; 2016

69. Whitty CJ, Chandler C, Ansah E, Leslie T, Staedke SG. Deployment of ACT antimalarials for treatment of malaria: challenges and opportunities. Malar J. 2008;7(Suppl 1):S7.

70. Ochodo E, Garner P, Sinclair D. Achieving universal testing for malaria. BMJ. 2016;352:107.

71. World Health Organization. Universal access to malaria diagonistic testing: an operational manual. Geneva: World Health Organization; 2011. Available at: https://www.who.int/malaria/publications/atoz/9789241502092/en/.

72. Juma E, Zurovac D. Changes in health workers' malaria diagnosis and treatment practices in Kenya. Malar J. 2011;10(1):1.

73. Zurovac D, Machini B, Kiptui R, Memusi D, Amboko B, Kigen S, Njiri P, Waqo $E$. Monitoring health systems readiness and inpatient malaria casemanagement at Kenyan county hospitals. Malar J. 2018;17(1):213.

74. Kallander K, Strachan D, Soremekun S, Hill Z, Lingam R, Tibenderana J, Kasteng F, Vassall A, Meek S, Kirkwood B. Evaluating the effect of innovative motivation and supervision approaches on community health worker performance and retention in Uganda and Mozambique: study protocol for a randomised controlled trial. Trials. 2015;16:157.

75. Githinji S, Kigen S, Memusi D, Nyandigisi A, Mbithi AM, Wamari A, Muturi AN, Jagoe G, Barrington J, Snow RW, et al. Reducing stock-outs of life saving malaria commodities using mobile phone text-messaging: SMS for life study in Kenya. PLoS One. 2013;8(1):e54066.

76. Hasselback L, Crawford J, Chaluco T, Rajagopal S, Prosser W, Watson N. Rapid diagnostic test supply chain and consumption study in Cabo Delgado, Mozambique: estimating stock shortages and identifying drivers of stock-outs. Malar J. 2014;13(1):295.

77. Bruxvoort K, Goodman C, Kachur SP, Schellenberg D. How patients take malaria treatment: a systematic review of the literature on adherence to antimalarial drugs. PLoS One. 2014;9(1):e84555.

78. Cohen JL, Yavuz E, Morris A, Arkedis J, Sabot O. Do patients adhere to overthe-counter artemisinin combination therapy for malaria? Evidence from an intervention study in Uganda. Malar J. 2012;11:83.

79. Mubi M, Janson A, Warsame M, Mårtensson A, Källander K, Petzold MG, Ngasala B, Maganga G, Gustafsson LL, Massele A, et al. Malaria rapid testing by community health workers is effective and safe for targeting malaria treatment: randomised cross-over trial in Tanzania. PLoS One. 2011;6(7): e19753.

80. Chanda P, Hamainza B, Moonga HB, Chalwe V, Pagnoni F. Community case management of malaria using ACT and RDT in two districts in Zambia: achieving high adherence to test results using community health workers. Malar J. 2011;10(1):158.

81. Kisia J, Nelima F, Otieno D, Killu K, Wamalwa E, Sohani S, Siekmans K, Nyandigisi A, Akhwale W. Factors associated with utilization of community health workers in improving access to malaria treatment among children in Kenya. Malar J. 2012;11(Suppl 1):142.

82. Mukanga D, Tibenderana J, Peterson S, Pariyo G, Kiguli J, Waiswa P, Babirye R, Ojiambo G, Kasasa S, Pagnoni F, et al. Access, acceptability and utilization of community health workers using diagnostics for case management of fever in Ugandan children: a crosssectional study. Malar J. 2012;11(1):121.

83. Winn LK, Lesser A, Menya D, Baumgartner JN, Kipkoech Kirui J, Saran I, Prudhomme-O'Meara W. Motivation and satisfaction among community health workers administering rapid diagnostic tests for malaria in Western Kenya. J Glob Health. 2018;8(1):010401.

84. Visser T, Bruxvoort K, Maloney K, Leslie T, Barat LM, Allan R, Ansah EK, Anyanti J, Boulton I, Clarke SE, et al. Introducing malaria rapid diagnostic tests in private medicine retail outlets: a systematic literature review. PLoS One. 2017;12(3):e0173093.

85. Maloney K, Ward A, Krenz B, Petty N, Bryson L, Dolkart C, Visser T, Le Menach A, Scott VK, Cohen JM, et al. Expanding access to parasite-based 
malaria diagnosis through retail drug shops in Tanzania: evidence from a randomized trial and implications for treatment. Malar J. 2017;16(1):6.

86. Cohen J, Fink G, Berg K, Aber F, Jordan M, Maloney K, Dickens W. Feasibility of distributing rapid diagnostic tests for malaria in the retail sector: evidence from an implementation study in Uganda. PLoS One. 2012;7(11):e48296.

87. Oduro AR, Maya ET, Akazili J, Baiden F, Koram K, Bojang K. Monitoring malaria using health facility based surveys: challenges and limitations. BMC Public Health. 2016;16(1):1-9.

88. Yukich J, Briët O, Bretscher MT, Bennett A, Lemma S, Berhane Y, Eisele TP, Keating J, Smith T. Estimating Plasmodium falciparum transmission rates in low-endemic settings using a combination of community prevalence and health facility data. PLoS One. 2012;7(8):e42861.

89. Kachur PS, Schulden J, Goodman CA, Kassala H, Elling BF, Khatib RA, Causer LM, Mkikima S, Abdulla S, Bloland PB. Prevalence of malaria parasitemia among clients seeking treatment for fever or malaria at drug stores in rural Tanzania 2004. Tropical Med Int Health. 2006;11(4):441-51.

90. Alegana VA, Wright J, Pezzulo C, Tatem AJ, Atkinson PM. Treatment-seeking behaviour in low- and middle-income countries estimated using a Bayesian model. BMC Med Res Methodol. 2017;17(1):67.

91. Dregan A, Grieve A, van Staa T, Gulliford MC. Potential application of itemresponse theory to interpretation of medical codes in electronic patient records. BMC Med Res Methodol. 2011;11(1):168.

92. Fox J-P, Wyrick C. A mixed effects randomized item response model. J Educ Behav Stat. 2008;33(4):389-415.

93. Rupp AA. Item response modeling with BILOG-MG and MULTILOG for Windows. Int J Test. 2003;3(4):365-84.

94. Maltha J, Gillet P, Jacobs J. Malaria rapid diagnostic tests in endemic settings. Clin Microbiol Infect. 2013;19(5):399-407.

95. Verma AK, Bharti PK, Das A. HRP-2 deletion: a hole in the ship of malaria elimination. Lancet Infect Dis. 2018;18(8):826-7.

96. Berhane A, Anderson K, Mihreteab S, Gresty K, Rogier E, Mohamed S, Hagos F, Embaye G, Chinorumba A, Zehaie A, et al. Major threat to malaria control programs by Plasmodium falciparum lacking histidine-rich protein 2, Eritrea. Emerg Infect Dis. 2018;24(3):462-70.

97. Beshir KB, Sepúlveda N, Bharmal J, Robinson A, Mwanguzi J, Busula AO, de Boer JG, Sutherland C, Cunningham J, Hopkins H. Plasmodium falciparum parasites with histidine-rich protein 2 (pfhrp2) and pfhrp3 gene deletions in two endemic regions of Kenya. Sci Rep. 2017;7(1):14718.

98. World Health Organization. Response plan to pfhrp2 gene deletions. Geneva: World Health Organization; 2019. Available at: https://www.who.int/ malaria/publications/atoz/response-plan-pfhrp2-gene-deletions/en/.

99. Baskaya M, Yuksel M, Erturkmen GBL, Cunningham M, Cunningham P. Health4Afrika - implementing HL7 FHIR based interoperability. Stud Health Technol Inform. 2019;264:20-4.

100. Maina JK, Macharia PM, Ouma PO, Snow RW, Okiro EA. Coverage of routine reporting on malaria parasitological testing in Kenya, 2015-2016. Glob Health Action. 2017;10(1):1413266.

101. Okello G, Gerrets R, Zakayo S, Molyneux S, Jones C. "Every day they keep adding new tools but they don't take any away": producing indicators for intermittent preventive treatment for malaria in pregnancy (IPTp) from routine data in Kenya. PLoS One. 2018;13(1):e0189699.

102. Crowell V, Yukich JO, Briët OJT, Ross A, Smith TA. A novel approach for measuring the burden of uncomplicated Plasmodium falciparum malaria: application to data from Zambia. PLoS One. 2013;8(2):e57297.

103. Nyangara FM, Hai T, Zalisk K, Ozor L, Ufere J, Isiguzo C, Abubakar IN. Assessment of data quality and reporting systems for underserved populations: the case of integrated community case management programs in Nigeria. Health Policy Plan. 2018;33(4):465-73.

104. Chilundo B, Sundby J, Aanestad M. Analysing the quality of routine malaria data in Mozambique. Malar J. 2004;3:3.

105. Okello G, Molyneux S, Zakayo S, Gerrets R, Jones C. Producing routine malaria data: an exploration of the micro-practices and processes shaping routine malaria data quality in frontline health facilities in Kenya. Malar J. 2019;18(1):420.

106. Howes RE, Mioramalala SA, Ramiranirina B, Franchard T, Rakotorahalahy AJ, Bisanzio D, Gething PW, Zimmerman PA, Ratsimbasoa A. Contemporary epidemiological overview of malaria in Madagascar: operational utility of reported routine case data for malaria control planning. Malar J. 2016; 15(1):502.

107. Ihantamalala FA, Rakotoarimanana FMJ, Ramiadantsoa T, Rakotondramanga JM, Pennober G, Rakotomanana F, Cauchemez S, Metcalf CJE, Herbreteau V,
Wesolowski A. Spatial and temporal dynamics of malaria in Madagascar Malar J. 2018;17(1):58.

108. Gething PW, Noor AM, Gikandi PW, Ogara EA, Hay SI, Nixon MS, Snow RW, Atkinson PM. Improving imperfect data from health management information systems in Africa using space-time geostatistics. PLoS Med. 2006;3(6):e271.

109. Bennett A, Yukich J, Miller JM, Vounatsou P, Hamainza B, Ingwe MM, Moonga HB, Kamuliwo M, Keating J, Smith TA, et al. A methodological framework for the improved use of routine health system data to evaluate national malaria control programs: evidence from Zambia. Popul Health Metrics. 2014;12(1):1-11.

110. Alegana VA, Atkinson PM, Wright JA, Kamwi R, Uusiku P, Katokele S, Snow RW, Noor AM. Estimation of malaria incidence in northern Namibia in 2009 using Bayesian conditional-autoregressive spatial-temporal models. Spat Spatio-Temporal Epidemiol. 2013;7:25-36.

111. Ssempiira J, Kissa J, Nambuusi B, Kyozira C, Rutazaana D, Mukooyo E, Opigo J, Makumbi F, Kasasa S, Vounatsou P. The effect of case management and vector-control interventions on space-time patterns of malaria incidence in Uganda. Malar J. 2018;17(1):162.

112. Boerma T, Mathers C. The World Health Organization and global health estimates: improving collaboration and capacity. BMC Med. 2015;13(1):50.

113. Maïga A, Jiwani SS, Mutua MK, Porth TA, Taylor CM, Asiki G, Melesse DY, Day C, Strong KL, Faye CM, et al. Generating statistics from health facility data: the state of routine health information systems in Eastern and Southern Africa. BMJ Glob Health. 2019;4(5):e001849.

114. Swaroop S, Gilroy AB, Uemura K. Statistical methods in malaria eradication. Monogr Ser World Health Organ. 1966;51:1-164.

115. Pampana E. A textbook of malaria eradication. 2nd ed. London: Oxford University Press; 1969.

116. Runge M, Snow RW, Molteni F, Thawer S, Mohamed A, Mandike R, Giorgi E, Macharia PM, Smith TA, Lengeler C, et al. Simulating the council-specific impact of anti-malaria interventions: a tool to support malaria strategic planning in Tanzania. PLoS One. 2020;15(2):e0228469.

117. Runge M, Molteni F, Mandike R, Snow RW, Lengeler C, Mohamed A, Pothin E. Applied mathematical modelling to inform national malaria policies, strategies and operations in Tanzania. Malar J. 2020;19(1):101.

118. Brunner NC, Chacky F, Mandike R, Mohamed A, Runge M, Thawer SG, Ross A, Vounatsou P, Lengeler C, Molteni F, et al. The potential of pregnant women as a sentinel population for malaria surveillance. Malar J. 2019; 18(1):370.

119. Kitojo C, Gutman JR, Chacky F, Kigadye E, Mkude S, Mandike R, Mohamed A, Reaves EJ, Walker P, Ishengoma DS. Estimating malaria burden among pregnant women using data from antenatal care centres in Tanzania: a population-based study. Lancet Glob Health. 2019;7(12):e1695-705.

120. WHO, RBM. High burden to high impact: a targeted malaria response. Geneva: WHO and RBM Partneship to End Malaria; 2018. Available at: https://www.who.int/malaria/publications/atoz/high-impact-response/en/.

121. Alegana VA, Wright J, Bosco C, Okiro EA, Atkinson PM, Snow RW, Tatem AJ, Noor AM. Malaria prevalence metrics in low- and middle-income countries: an assessment of precision in nationally-representative surveys. Malar J. 2017;16(1):475.

122. Tusting LS, Bousema T, Smith DL, Drakeley C. Chapter three - measuring changes in Plasmodium falciparum transmission: precision, accuracy and costs of metrics. In: Rollinson D, editor. Advances in parasitology. Volume 84: Academic Press; 2014. p. 151-208..

123. O'Meara WP, Collins WE, McKenzie FE. Parasite prevalence: a static measure of dynamic infections. Am J Trop Med Hyg. 2007;77(2):246-9.

124. AbouZahr C, de Savigny D, Mikkelsen L, Setel PW, Lozano R, Nichols E, Notzon F, Lopez AD. Civil registration and vital statistics: progress in the data revolution for counting and accountability. Lancet. 2015;386(10001): 1373-85.

125. Jackson D, Wenz K, Muniz M, Abouzahr C, Schmider A, Bratschi MW, Braschi MW, Kassam N, Diaz T, Mwamba R, et al. Civil registration and vital statistics in health systems. Bull World Health Organ. 2018;96(12):861-3.

126. Rowe AK, Rowe SY, Snow RW, Korenromp EL, Schellenberg JRA, Stein C, Nahlen BL, Bryce J, Black RE, Steketee RW. The burden of malaria mortality among African children in the year 2000. Int J Epidemiol. 2006;35(3):691-704.

127. Liu L, Oza S, Hogan D, Chu Y, Perin J, Zhu J, Lawn JE, Cousens S, Mathers C, Black RE. Global, regional, and national causes of under-5 mortality in 200015: an updated systematic analysis with implications for the Sustainable Development Goals. Lancet. 2016;388(10063):3027-35. 
128. Alkema L, You D. Child mortality estimation: a comparison of UN IGME and IHME estimates of levels and trends in under-five mortality rates and deaths. PLoS Med. 2012;9(8):e1001288.

129. Korenromp E, Arnold F, Williams B, Nahlen B, Snow R. Monitoring trends in under-5 mortality rates through national birth history surveys. Int J Epidemiol. 2004;33(6):1293-301.

130. Setel PW, Macfarlane SB, Szreter S, Mikkelsen L, Jha P, Stout S, AbouZahr C. A scandal of invisibility: making everyone count by counting everyone. Lancet. 2007;370(9598):1569-77.

131. Mahapatra P, Shibuya K, Lopez AD, Coullare F, Notzon FC, Rao C, Szreter S. Civil registration systems and vital statistics: successes and missed opportunities. Lancet. 2007;370(9599):1653-63.

132. Lopez AD, AbouZahr C, Shibuya K, Gollogly L. Keeping count: births, deaths, and causes of death. Lancet. 2007;370(9601):1744-6.

\section{Publisher's Note}

Springer Nature remains neutral with regard to jurisdictional claims in published maps and institutional affiliations.

Ready to submit your research? Choose BMC and benefit from:

- fast, convenient online submission

- thorough peer review by experienced researchers in your field

- rapid publication on acceptance

- support for research data, including large and complex data types

- gold Open Access which fosters wider collaboration and increased citations

- maximum visibility for your research: over $100 \mathrm{M}$ website views per year

At BMC, research is always in progress.

Learn more biomedcentral.com/submissions 